\title{
Sphygmomanometer test to evaluate muscle strength in individuals with lower limb amputation: validity and reliability
}

\author{
Teste do esfigmomanômetro para avaliação da \\ força muscular em indivíduos com amputações de \\ membros inferiores: validade e confiabilidade
}

Fabiana Amaral de Carvalho ${ }^{[a]}$, Letícia Cristina Carvalho Silva ${ }^{[a]}$, Regina Adriana Nogueira ${ }^{[a]}$, Stella Maria Cândido Camargos ${ }^{[a]}$, Andressa Silva ${ }^{[b]}$, Viviane Santos Borges ${ }^{[a]^{*}}$

[a] Universidade de Itaúna (UI), Itaúna, MG, Brazil

[b] Universidade Federal de Minas Gerais (UFMG), Belo Horizonte, MG, Brazil

\begin{abstract}
Introduction: The sphygmomanometer test is an alternative and inexpensive method for assessment of muscle strength. This instrument was considered valid and reliable to measure the isometric strength in different health conditions, however, in individuals with limb amputations the properties of this instrument for this purpose, have not been investigated. Objective: To investigate the concurrent criterion validity, test-retest and inter-rater reliabilities of the aneroid sphygmomanometer test (AST) without modification, for assessment of the strength of subjects with lower limb amputations. Methods: Twenty-two subjects ( $57.6 \pm 15.2$ years) with lower limb amputations were included in this study. Maximum isometric force was assessed with a handheld dynamometer (microFet $2^{\circledR}$ ) and the AST. To identify differences between trials, one-way ANOVA was applied. To assess the concurrent criterion validity, test-retest and inter-rater reliabilities of the AST, Pearson's correlation coefficients
\end{abstract}

\footnotetext{
* FAC: BS, e-mail: fabianaitauna@hotmail.com LCCS: BS, e-mail: leticiacrvalho_60@hotmail.com RAN: BS, e-mail: nog13re@gmail.com SMCC: BS, e-mail: stellamccn@gmail.com AS: PhD, e-mail: silvadressa@gmail.com VSB: MS, e-mail: visb.edu@gmail.com
} 
of determination and intra-class correlation coefficient (ICC) were calculated. Results: For all muscle groups, no differences were observed between the trials $(0.00001 \leq F \leq 0.10 ; 0.90 \leq p \leq 0.99)$. Significant, positive, and high to very high correlations were found between the HHD and the AST measures for the different numbers of trials for all assessed muscles $(0.76 \leq \mathrm{r} \leq 0.93 ; \mathrm{p} \leq 0.02)$. Test-retest $(0.67 \leq$ ICC $\leq 0.97)$ and inter-rater reliabilities $(0.78 \leq$ ICC $\leq 0.97)$ were adequate. The values obtained with the AST were good predictors of those obtained with HHD $\left(0.58 \leq r^{2} \leq 0.85\right)$. Conclusion: For individuals with lower limb amputation, the AST showed adequate concurrent criterion validity, test-retest reliability and inter-rater reliability for the assessment of lower limbs muscle strength.

Keywords: Sphygmomanometer. Amputation. Data Accuracy. Muscle Strength. Validity of Tests.

\section{Resumo}

Introdução: $O$ teste do esfigmomanômetro é um método alternativo e de baixo custo para se avaliar a força muscular. Esse instrumento já foi considerado válido e confiável para mensurar a forç̧a isométrica em diversas condições de saúde. No entanto, em indivíduos com amputações de membros as propriedades desse instrumento para esse fim, ainda não foram investigadas. Objetivo: Investigar a validade de critério concorrente, a confiabilidade teste-reteste e entre examinadores, do teste do esfigmomanômetro aneroide (TEA) sem modificação, para a avaliação da força muscular de indivíduos com amputações de membros inferiores (MMII). Métodos: Participaram 22 indivíduos (57,6 \pm 15,2 anos) com amputações de MMII. A força isométrica máxima foi avaliada através de um dinamômetro portátil (microFet ${ }^{\circledR}$ ) e do TEA. Para identificar diferenças entre as repetições, ANOVA one-way foi utilizada. Para avaliar a validade do critério concorrente, confiabilidade teste-reteste e entre examinadores do TEA, os coeficientes de correlação de Pearson, de determinação e coeficiente de correlação intra-classe (CCI) foram calculados. Resultados: Para todos os grupos musculares, não foram observadas diferenças nas repetições $(0,00001 \leq F \leq 0,10 ; 0,90 \leq p \leq 0,99)$. Os resultados apresentaram correlação positiva elevada e muito elevada para as diferentes medidas e grupos musculares dos MMII $(0,76 \leq r \leq 0,93 ; p \leq 0,02)$. E confiabilidade teste-reteste $(0,67 \leq I C C \leq 0,97)$ e entre examinadores $(0,78 \leq$ ICC $\leq 0,97)$ consideráveis. Os valores obtidos com o TEA foram bons preditores daqueles obtidos com o dinamômetro manual $\left(0,58 \leq r^{2} \leq 0,85\right)$. Conclusão: Para indivíduos com amputações de membros, o TEA apresentou valores adequados de validade de critério concorrente, confiabilidade teste-reteste e entre examinadores, para a avaliação de força muscular de MMII.

Palavras-chave: Esfigmomanômetro. Amputação. Confiabilidade dos Dados. Força Muscular. Validade dos Testes.

\section{Introduction}

Individuals with lower limb amputations of traumatic or elective origin (1) present diverse physical, psychological and social changes $(2-6)$. Therefore, emphasizing the complex process of functionality/disability, amputation is related to a disarrangement in all the factors that guide this process (4). Regarding the physical factors, limb loss generates changes in muscle strength and balance, increasing energy expenditure $(2,6,7)$, causing functional limitations and changes in the participation in individual and social activities $(3,6)$.

Because amputation is an aggravating physical condition, the evaluation of muscle strength by means of quantitative methods is essential for the success of the therapeutic management $(3-5,8-13)$. The primary objective of rehabilitation after amputation is the fitting of a prosthesis $(2,13,14)$, with this condition being dependent on good muscle strength $(3-5,14)$. 
There are many ways to measure muscle strength in individuals with amputation $(3,7,9,15,16)$, however most of them present high costs, making them unusable in the clinical practice. Therefore, the physiotherapist uses subjective resources of limited reliability to quantify muscle strength $(13,17,18)$. Based on this assumption, many researchers have investigated the validity and reliability of equipment such as the sphygmomanometer, an instrument already established to measure blood pressure (19), to evaluate the isometric muscle strength of individuals with different health conditions $(9-12,20,21)$. Considering the positive results of these investigations, the hypothesis of the present study was that the aneroid sphygmomanometer test (AST) could be a potential instrument to evaluate the muscle strength of individuals with limb amputations.

The sphygmomanometer represents a favorable alternative due to being portable and basic equipment of the health professional (19) and is highlighted when the cost is taken into account. In addition, satisfactory results of concurrent criterion validity $(0.75 \leq r \leq 0.90 ; p \leq 0.001)$, test-retest reliability $(0.77 \leq$ ICC $\leq 0.98 ; \mathrm{p} \leq 0.001)$ and interrater reliability $(0.53 \leq$ ICC $\leq 0.91, p \leq 0.001)$ have guaranteed the use of the equipment for measuring strength directed at various muscle groups (10). The aneroid sphygmomanometer test (AST) has also been used to evaluate the strength of healthy individuals $(22,12)$ and those with various health conditions, such as Parkinson's disease (11), stroke $(9,10)$, neck pain $(21)$, hip fracture $(23)$ and rheumatoid arthritis (20).

The concurrent criterion validity indicates that the instrument is adequate to measure the strength and can be compared to portable instruments that are gold standard $(24-26,10)$. The use of the AST to evaluate the muscle strength of individuals with amputations may be an alternative of choice to complement the evaluations. Both validity and reliability of this instrument for measuring the muscle strength of these individuals are fundamental for it to become a reliable and valid option for use in studies and mainly in the clinical practice.

As mentioned, measuring muscle strength gain in individuals with limb amputations is a strategic determinant for the clinical evaluation $(3-5,8)$, because after the fitting of a prosthesis, muscle mass gain attenuates the gait asymmetries $(6,7)$. Due to increased energy expenditure during walking, patients opt for a more economical velocity (7), however, the more muscle strength individuals gain, the more they increase the walking ability $(2,6,7,15)$.

Thus, the aim of the present study was to investigate the concurrent criterion validity, testretest reliability and inter-rater reliability, of the unmodified AST in the evaluation of the muscle strength of individuals with lower limb amputations.

\section{Methods}

The present study was evaluated and approved by the Research Ethics Committee of the University of Itaúna (No. 1.333.943), considering the requirements of Resolution No. 510/2016 of the National Health Council.

Sample

The study was performed with volunteers, with unilateral or bilateral lower limb amputations, who were recruited from the Amputee Sports Association of Minas Gerais (AMDA - Belo Horizonte), the Integrated Physiotherapy Clinics of the University of Itaúna and the Primary Health Units of the municipalities of Itaúna and Itatiaiuçu of Minas Gerais state. After providing consent, the evaluations were carried out at the centers involved or in the home of the volunteer. All individuals who participated in the study signed a consent form.

Female and male volunteers who presented lower limb amputation of traumatic or elective origin, with time since the amputation of four months or more and aged over 20 years were included in the study. The individuals who presented the following were excluded; cognitive alterations or the inability to understand the proposed tests $(10,15)$; contractures in the residual limb; pain in the joints involved; residual pain or phantom pain (27) greater than three on the Visual Analogue Scale (VAS) (28); residual limb of less than $10 \mathrm{~cm}$ in length and other health conditions that could alter the strength of the lower limb $(3,7,15,29)$. 
Equipment for Muscle Strength Measurement

For the measurement of the isometric muscular force, the Tyros ${ }^{\circledR}$ brand aneroid sphygmomanometer (AS) (WelchAllyn Inc., NY, USA, Model DS-44) was used, unmodified, with the units of measurement in mmHg. For its use in the study, the equipment was inflated to $100 \mathrm{mmHg}$ to remove possible folds, and then deflated to $20 \mathrm{mmHg}$, keeping the valve closed, establishing a measurement range of 20 to $304 \mathrm{mmHg}(9,10$, 20 ). For methodological control, this procedure was repeated with each test (10).

In order to investigate the concurrent criterion validity, the force in Newtons (N) was measured using a microFet ${ }^{\circledR}$ Handheld Dynamometer (HHD) (HogganHealth Industries, Salt Lake City, UT, USA), considered a gold standard for isometric strength measurement $(9,10,24,25)$. A digital timer (Casio HS-30W) was also used to measure the duration of the force pressures obtained with the AST.

\section{Procedures}

The test-retest reliability evaluates the consistency of the measurements performed under the same evaluation conditions at two different times. Inter-rater reliability, on the other hand, evaluates the consistency of the measurements performed by two different examiners (30). Thus, according to established procedures, the participants were evaluated in two moments by two previously trained evaluators (Examiner 1 and 2 ), with an average interval of 10 days between the first and second evaluation, following the same criteria of evaluation, such as: administration, location, time, instruction and protocols.

On the first day, for investigation and collection of data, the volunteers responded to an evaluation form containing demographic data, anthropometric data and clinical data related to the amputation. In addition, they were informed of the objectives and methods of the study, and then underwent the first strength evaluation using the AST and HHD.

The order of use of the equipment (AST and HHD) was randomized before each evaluation through a simple draw $(10,9)$. An approximate interval of five minutes between the measurement of each piece of equipment was established (9). The examiners applied manual resistance against the force exerted by the volunteer, keeping the limb in question static ( 9 - 11). To assist each examiner, two other researchers helped in the tests, controlling the time, reading the equipment $(9,10,24,25)$ and recording the data, so that the examiners who were operating the equipment were not influenced by the transcription of the data $(10,30)$.

Previously, for familiarization training for the test, the volunteers performed submaximal isometric contraction. Only the affected side was evaluated and in cases of bilateral amputation, the residual limb of greater length was the side considered for the analysis $(3,7,12,15,29)$. The muscle groups evaluated depended on the level of the amputation. For the transfemoral amputations, the muscle groups evaluated were: flexors, extensors and hip abductors. For evaluation of the flexor muscles of the hip the volunteer remained seated in a chair with a backrest, maintaining $90^{\circ}$ flexion of the hip and contralateral knee (3, 31 ). In order to perform this test, the volunteer was allowed to hold the edges of the chair for stabilization, and the isometric movement was performed, resisted by the examiner (31), with the equipment positioned on the anterior surface of the residual limb. For the evaluation of hip extensors, the volunteer was placed in the ventral decubitus (VD) position and the equipment was positioned on the posterior surface of the residual limb (31). For the evaluation of the hip abductor muscles, the volunteer was lying in lateral decubitus (LD) position, with the contralateral limb kept flexed and the equipment positioned on the lateral side of the residual limb $(3,32)$.

In the transtibial amputations and disarticulations of the foot, the muscle groups evaluated were knee flexors and extensors. For the evaluation of the extensors, the volunteer remained seated in a chair with back, hips and knees flexed at $90^{\circ}(10,15,31)$. For this movement, the volunteer was allowed to hold the edges of the chair (31). The devices were positioned on the anterior surface of the residual limb. For the knee flexor muscles, the volunteer was lying in the VD position with the contralateral knee in extension and the amputated limb at $45^{\circ}$ flexion (33). The equipment was positioned on the posterior surface of the residual limb.

The measuring instruments, AST and HHD, were positioned $5 \mathrm{~cm}$ from the distal end of the residual 
limb to resist the isometric motion. During the tests, the volunteers were verbally encouraged to perform the maximum isometric contraction, maintaining it for 5 seconds (s) $(9-11,15,31)$. The examiners applied manual resistance, contrary to the force exerted by the volunteer, keeping the limb static. Six measurements were performed, three with HHD and three with AST $(9,10,15)$. Peak force values were recorded. A rest interval of $15 \mathrm{~s}$ was given between each measurement (10). All the care with testing and operations related to the muscular force test, such as positioning, equipment calibration, and pre-test care, were observed and performed following all the observations suggested by the manufacturers. If a prosthesis was used, it was removed for the tests.

\section{Sample Calculation}

To determine the sample size, a previous pilot study was performed with 10 individuals with lower limb amputations (30). For the determination of the calculation, the lowest value of the coefficient of determination obtained for the different muscle groups was considered: $r^{2}=0.57$. Using a Power of 0.90 and an $\alpha=0.05$ significance level, $n=11$ was found. As individuals of different age groups would be investigated, two groups, 11 adults ( $20 \leq \mathrm{n}<60$ years) and 11 older adults ( $\geq 60$ years), were determined to attenuate the assumptions of sample variability (30). All data analyzes were performed with all the subjects pooled. For the calculation of the sample size, the statistical program G-Power ${ }^{\odot}$, version 3.1.9.2 (Franz Faul, Universität Kiel, Germany, 1992-2014) was used.

\section{Statistical Analysis}

Descriptive statistics and normality tests were performed. In order to compare the results obtained with the AST, one-way ANOVA was used considering the measurements obtained by examiners 1 and 2 , on the first day, using different repetitions (first repetition, mean of 1 st and 2 nd repetition and mean of the three repetitions) for all muscle groups $(9,10)$. For the analysis of the concurrent criterion validity of the AST, Pearson's correlation coefficient was used to determine the correlation between muscle strength measurements obtained with the $\operatorname{HHD}(N)(24,25)$ and with the AST ( $\mathrm{mmHg}$ ), for each of the muscle groups evaluated. Linear regression analyzes were performed to identify the best model, which could explain the relationship between the measurements obtained with the two pieces of equipment and thus present the regression equations to predict the strength values, in $\mathrm{N}$, through those obtained in $\mathrm{mmHg}$ by the AST.

For the analysis of the reliability of the AST, the intra-class correlation coefficient (ICC) was used, with 95\% confidence interval (CI), for the interrater measurements obtained and for the analysis of the test-retest reliability. For the ICC values that showed significant results, the magnitude of the correlation was classified as previously described (34). For the correlations that presented significant results, the magnitude of the correlation was classified as follows: $0-0.25$ very low; $0.26-0.49$ low; 0.50-0.69 moderate; 0.70-0.89 high; 0.90-1.00 very high. Systematic differences between the two sessions, test-retest or inter-rater reliability were verified through paired t-tests, presenting 95\% CI of the mean of the difference. All the analyzes were performed using the SPSS statistical package for Windows (version 22.0). The level of significance was $\alpha=0.05$.

\section{Results}

For the analysis of the of the concurrent criterion validity of the AST, 22 individuals with lower limb amputations were evaluated (Table 1). For the tests of test-retest and inter-rater reliability 18 individuals were evaluated, with a mean age of 58.6 (15.9) years, mean time since the amputation of 10.73 (14.5) years. Four volunteers did not participate in the second evaluation because they were unable to attend. The majority of the individuals underwent elective amputation as a result of peripheral vascular disease or diabetes.

Table 2 presents the values obtained from the three repetitions considered for analysis of strength measurement. As no differences were observed $(0.00001 \leq F \leq 0.10 ; 0.90 \leq p \leq 0.99)$, analysis of the validity and reliability data were performed considering the three repetitions. 
Table 1 - Demographic and clinical data $(n=22)$

\begin{tabular}{|c|c|}
\hline Variables & Results \\
\hline Age (years), mean (SD) [min.-max] & $57.6(15.2)[21-82]$ \\
\hline Height (cm), mean (SD) & $1.67(0.08)$ \\
\hline Body mass (kg), mean (SD) & $73.9(12.8)$ \\
\hline BMI $\left(\mathrm{kg} / \mathrm{m}^{2}\right)$, mean (SD) & $26.3(3.7)$ \\
\hline Amputation time (years), mean (SD) [min.-max] & 12.2 (15) [4 months-54 years] \\
\hline Male, n (\%) & $16(72.7)$ \\
\hline \multicolumn{2}{|l|}{ Amputation Level, $\mathrm{n}(\%)$} \\
\hline Transfemoral & $14(63.6)$ \\
\hline Transtibial & $5(22.7)$ \\
\hline Chopart's & $3(13.6)$ \\
\hline Residual Limb (cm), mean (DP) [min.-max] & $30.4(10.4)[11-49]$ \\
\hline \multicolumn{2}{|l|}{ Amputation Side, n (\%) } \\
\hline Left & $13(59.1)$ \\
\hline Right & $7(31.8)$ \\
\hline Bilateral & $2(9)$ \\
\hline \multicolumn{2}{|l|}{ Cause, $n(\%)$} \\
\hline Elective & $12(55)$ \\
\hline Traumatic & $10(45)$ \\
\hline \multicolumn{2}{|l|}{ Laterality, n (\%) } \\
\hline Right-handed & $21(95.5)$ \\
\hline Left-handed & $1(4.5)$ \\
\hline \multicolumn{2}{|l|}{ Sedentary, n (\%) } \\
\hline Yes & $17(77.3)$ \\
\hline No & $5(22.7)$ \\
\hline \multicolumn{2}{|l|}{ Use of Prosthesis, $n$ (\%) } \\
\hline No & $13(59.1)$ \\
\hline Yes & $9(40.9)$ \\
\hline
\end{tabular}

Note: $\mathrm{SD}=$ Standard deviation; BMI = Body mass index. Disarticulation of the foot.

Table 2 - Descriptive data of muscle strength with different forms of measurement, AST (mmHg) and HHD (N), and results of the analysis of variance (ANOVA) among the three repetitions investigated, considering the first session and examiners $l$ and $2, n=22$

\begin{tabular}{lcccc}
\hline $\begin{array}{l}\text { Muscle Group } \\
\text { (measurement) }\end{array}$ & First Repetition & $\begin{array}{c}\text { Mean of the two } \\
\text { repetitions (1 and 2) }\end{array}$ & $\begin{array}{c}\text { Mean of the three } \\
\text { repetitions (1, 2 and 3) }\end{array}$ & $\begin{array}{c}\text { ANOVA } \\
(\boldsymbol{F} ; \boldsymbol{p} \text {-value) }\end{array}$ \\
\hline Abd. HHD & $\begin{array}{c}\text { Examiner } \mathbf{1} \\
\text { Mean }(S D)\end{array}$ \\
Abd. AST & $155.5(57.9)$ & $154.61(59.7)$ & $155.36(60)$ & $0.00 ; 0.99$ \\
Hip flex. HHD & $189.2(65.4)$ & $191.2(59.7)$ & $192(58)$ & $0.00 ; 0.99$ \\
Hip flex. AST & $145.33(48.2)$ & $143.3(44.3)$ & $146.7(45.8)$ & $0.01 ; 0.98$ \\
Hip ex. HHD & $156.7(52)$ & $162.9(55.7)$ & $165.7(54.9)$ & $0.10 ; 0.90$ \\
& $118.3(66.7)$ & $123.6(66.6)$ & $127.4(66.4)$ & $0.06 ; 0.93$ \\
\hline
\end{tabular}


(Conclusion)

Table 2 - Descriptive data of muscle strength with different forms of measurement, AST (mmHg) and HHD (N), and results of the analysis of variance (ANOVA) among the three repetitions investigated, considering the first session and examiners 1 and $2, n=22$

\begin{tabular}{lcccc}
\hline $\begin{array}{l}\text { Muscle Group } \\
\text { (measurement) }\end{array}$ & First Repetition & $\begin{array}{c}\text { Mean of the two } \\
\text { repetitions }(\mathbf{l} \text { and } 2)\end{array}$ & $\begin{array}{c}\text { Mean of the three } \\
\text { repetitions }(\mathbf{1}, \mathbf{2} \text { and } 3 \text { ) }\end{array}$ & $\begin{array}{c}\text { ANOVA } \\
(\boldsymbol{F} ; \boldsymbol{p} \text {-value })\end{array}$ \\
\hline Hip ex. AST & $139.4(74)$ & $140(74)$ & $142(72)$ & $0.00 ; 0.99$ \\
Knee flex. HHD & $104.9(71)$ & $100(69.3)$ & $99(65.2)$ & $0.01 ; 0.98$ \\
Knee flex. AST & $133(75.8)$ & $140.9(78.4)$ & $140.8(77.7)$ & $0.02 ; 0.97$ \\
Knee ex. HHD & $99.6(56.4)$ & $106.7(57.9)$ & $109.3(60.4)$ & $0.06 ; 0.94$ \\
Knee ex. AST & $135.7(75.9)$ & $136(72.4)$ & $137.6(71)$ & $0.00 ; 0.99$ \\
\hline & & Examiner 2 & \\
\hline Abd. HHD & Mean (SD) & & $0.00 ; 0.99$ \\
Abd. AST & $152(47)$ & $152.8(47)$ & $152(48)$ & $0.04 ; 0.95$ \\
Hip flex. HHD & $185.6(58.5)$ & $186.9(61.9)$ & $0.00 ; 0.99$ \\
Hip flex. AST & $180.8(53.7)$ & $153.9(50.5)$ & $154(49.7)$ & $0.08 ; 0.92$ \\
Hip ex. HHD & $152.9(48.5)$ & $159.6(41)$ & $163.7(44.1)$ & $0.02 ; 0.97$ \\
Hip ex. AST & $157.3(42.4)$ & $124.9(58)$ & $124.4(56.3)$ & $0.01 ; 0.98$ \\
Knee flex. HHD & $129.2(60.5)$ & $143.4(59)$ & $145(60.4)$ & $0.00 ; 0.99$ \\
Knee flex. AST & $141.7(61.3)$ & $102.9(55.8)$ & $99.8(53.7)$ & $0.01 ; 0.98$ \\
Knee ex. HHD & $100.8(64.4)$ & $123.7(61)$ & $126(62)$ & $0.03 ; 0.96$ \\
Knee ex. AST & $120.6(61)$ & $102.2(58.4)$ & $101.7(60)$ & $0.01 ; 0.98$ \\
\hline
\end{tabular}

Note: $\mathrm{SD}=$ standard deviation; $\mathrm{Abd}=$ abductors; flex = flexors; $\mathrm{ex}=$ extensors; $\mathrm{AST}$ = aneroid sphygmomanometer test; $\mathrm{HHD}=$ handheld dynamometer.

Validity

Table 3 presents the correlation values and regression analysis between the AST and HHD. There was a high and very high positive correlation for the lower limb muscle groups $(0.76 \leq r \leq 0.93 ; p \leq 0.02)$.

The results of the linear regression analysis $\left(r^{2}\right)$, obtained in the first session (repetition 1), indicated that the values presented by the AST were good predictors of those obtained by the HHD. According to the results of the determination coefficient, at least $58 \%$ of the values obtained with the HHD, in N, were explained by the values obtained with the AST, in $\mathrm{mmHg}$, for all muscle groups. The equations shown in Table 3 can be used to predict the strength values in $\mathrm{N}$, through the measurements obtained by the AST in mmHg.

Table 3 - Descriptive statistics (mean \pm SD), Pearson's correlation coefficient and regression analysis $\left(r^{2}\right)$ of the first force repetition, presenting data from examiners $l$ and 2 , on the first day of evaluation, $n=22$

\begin{tabular}{lccccc}
\hline $\begin{array}{l}\text { Muscle Group } \\
\text { (measurement) }\end{array}$ & $\begin{array}{c}\text { HHD } \\
\text { (Mean and SD) }\end{array}$ & $\begin{array}{c}\text { AST } \\
\text { (Mean and SD) }\end{array}$ & Correlation $(r)$ & Regression $\left(r^{2}\right)$ & $\begin{array}{c}\text { Regression } \\
\text { (Equation) }\end{array}$ \\
\hline Examiner 1 \\
\hline Abductors & $155.5(57.9)$ & $189.2(65.4)$ & $0.85^{*}$ & $0.71^{*}$ & $\mathrm{Y}=13.82+0.74(\mathrm{x})$ \\
Hip flexors & $145.3(48.2)$ & $156.7(52.1)$ & $0.77^{*}$ & $0.59^{*}$ & $\mathrm{Y}=33.3+0.71(\mathrm{x})$ \\
Knee flexors & $118.3(66.7)$ & $139.4(74)$ & $0.86^{*}$ & $0.74^{*}$ & $\mathrm{Y}=9.8+0.77(\mathrm{x})$ \\
Knee extensors & $104.9(71)$ & $133(75.8)$ & $0.93^{*}$ & $0.85^{*}$ & $\mathrm{Y}=-11.7+0.87(\mathrm{x})$ \\
& $99.6(56.4)$ & $135.7(75.9)$ & $0.85^{*}$ & $0.73^{*}$ & $\mathrm{Y}=4+0.8(\mathrm{x})$ \\
\hline
\end{tabular}


(Conclusion)

Table 3 - Descriptive statistics (mean \pm SD), Pearson's correlation coefficient and regression analysis $\left(r^{2}\right)$ of the first force repetition, presenting data from examiners 1 and 2 , on the first day of evaluation, $n=22$

\begin{tabular}{lccccc}
\hline $\begin{array}{l}\text { Muscle Group } \\
\text { (measurement) }\end{array}$ & $\begin{array}{c}\text { HHD } \\
\text { (Mean and SD) }\end{array}$ & $\begin{array}{c}\text { AST } \\
\text { (Mean and SD) }\end{array}$ & Correlation $(r)$ & Regression $\left(r^{2}\right)$ & $\begin{array}{c}\text { Regression } \\
\text { (Equation) }\end{array}$ \\
\hline \multicolumn{5}{c}{ Examiner 2} \\
\hline Abductors & $152.6(47.2)$ & $180.8(53.7)$ & $0.85^{*}$ & $0.72^{*}$ & $\mathrm{Y}=17+0.75(\mathrm{x})$ \\
Hip Flexors & $152.9(48.5)$ & $157.3(42.5)$ & $0.88^{*}$ & $0.78^{*}$ & $\mathrm{Y}=-5.12+1(\mathrm{x})$ \\
Hip extensors & $129.2(60.5)$ & $141.7(61.3)$ & $0.78^{*}$ & $0.61^{*}$ & $\mathrm{Y}=19.2+0.77(\mathrm{x})$ \\
Knee flexors & $100.8(64.4)$ & $120.6(61)$ & $0.76^{*}$ & $0.58^{*}$ & $\mathrm{Y}=3.73+0.80(\mathrm{x})$ \\
Knee extensors & $95(54.9)$ & $120.6(47)$ & 0.81 & $0.67^{*}$ & $\mathrm{Y}=-19.6+0.95(\mathrm{x})$ \\
\hline
\end{tabular}

Note: ${ }^{*} p \leq 0.001 ;{ }^{* \star} p \leq 0.003 ; " p \leq 0.02$. SD = standard deviation; $y=$ dependent variable or criterion variable (manual dynamometer); $\mathrm{x}=$ independent or predictive variable (sphygmomanometer).

Reliability

According to the results of the test-retest reliability of the AST, considering the three measurements and the two examiners, ICC $\geq 0.81$ and ICC $\geq 0.67$ were observed for the knee and hip flexor and extensor musculature and hip abductors, respectively (Table 4). High and very high values were presented for the knee and hip flexors and extensors and moderate or high for the hip abductors.

Evaluating the results of the inter-rater reliability (Table 5), high or very high values
$(0.78 \leq$ ICC $\leq 0.97)$ were observed for all lower limb muscle groups using the AST. No differences were observed between the evaluators or between the two days of evaluation.

In general, the $95 \% \mathrm{CI}$ of the test-retest (Table 4) and inter-rater reliabilities (Table 5) presented a wide variation between the different repetitions. For the hip abductors, related to the second evaluator, in the test-retest reliability test the ICC was below 0.70 , this being moderate. The 95\% CI of the ICC were broad and the ranges included zero.

Table 4 - Intra-Class Correlation Coefficient (ICC) values for the test-retest reliability test using the AST to evaluate the strength of the hip abductor muscles; flexor and extensor muscles of the hip and knee, considering the measurements in the two distinct sessions, including data from examiner $l$ and $2, n=18$

\begin{tabular}{|c|c|c|c|c|c|c|c|c|c|}
\hline \multirow{2}{*}{$\begin{array}{l}\text { Muscular } \\
\text { Group } n=18\end{array}$} & \multicolumn{3}{|c|}{ First Repetition } & \multicolumn{3}{|c|}{$\begin{array}{l}\text { Mean of the } 1^{\text {st }} \text { and } 2^{\text {nd }} \\
\text { Repetition }\end{array}$} & \multicolumn{3}{|c|}{$\begin{array}{c}\text { Mean of the } 1^{\text {st }}, 2^{\text {nd }} \text { and } 3^{\text {rd }} \\
\text { Repetition }\end{array}$} \\
\hline & ICC & $\begin{array}{l}95 \% \mathrm{Cl} \text { of } \\
\text { the ICC }\end{array}$ & $\begin{array}{c}95 \% \mathrm{Cl} \\
\text { of the } \\
\text { difference of } \\
\text { the means }\end{array}$ & ICC & $\begin{array}{l}95 \% \mathrm{Cl} \text { of } \\
\text { the ICC }\end{array}$ & $\begin{array}{c}95 \% \mathrm{Cl} \\
\text { of the } \\
\text { difference of } \\
\text { the means }\end{array}$ & ICC & $\begin{array}{l}95 \% \mathrm{Cl} \text { of } \\
\text { the ICC }\end{array}$ & $\begin{array}{c}95 \% \mathrm{Cl} \\
\text { of the } \\
\text { difference of } \\
\text { the means }\end{array}$ \\
\hline \multicolumn{10}{|c|}{ Examiner 1} \\
\hline Hip abductors & 0.75 & $0.09-0.93$ & $-49-19.35$ & 0.82 & $0.36-0.95$ & $-43.7-14.2$ & 0.82 & $0.35-0.95$ & $-42.8-13.9$ \\
\hline Hip flexors & 0.85 & $0.45-0.96$ & $-52--15.5$ & 0.92 & $0.73-0.98$ & $-38.6--12$ & 0.87 & $0.54-0.96$ & $-40--4.71$ \\
\hline Hip extensors & 0.91 & $0.69-0.97$ & $-41.6--8.4$ & 0.88 & $0.58-0.97$ & $-43.3--4.6$ & 0.89 & $0.62-0.97$ & $-38.7--2.2$ \\
\hline Knee flexors & 0.97 & 0.83-0.99 & $-0.35-11$ & 0.96 & $0.82-0.99$ & $-34-14.6$ & 0.95 & $0.74-0.99$ & $-42.5-16.4$ \\
\hline Knee extensors & 0.89 & $0.38-0.98$ & $-46.5-36.6$ & 0.90 & $0.43-0.98$ & $-51-29.8$ & 0.85 & $0.12-0.97$ & $-69.4-31.2$ \\
\hline \multicolumn{10}{|c|}{ Examiner 2} \\
\hline Hip abductors & 0.69 & $-0.14-0.91$ & $-29.3-37.1$ & 0.67 & $-0.20-0.91$ & $-30.5-39$ & 0.69 & $-0.14-0.91$ & $-35.5-34.6$ \\
\hline Hip flexors & 0.87 & $0.53-0.96$ & $-12.1-25.2$ & 0.85 & $0.46-0.96$ & $13.4-27.8$ & 0.84 & $0.42-0.95$ & $15.6-28.5$ \\
\hline Hip extensors & 0.81 & $0.29-0.94$ & $-32.9-16$ & 0.85 & $0.45-0.96$ & $-27-13$ & 0.87 & $0.52-0.97$ & $-21.5-17.7$ \\
\hline Knee flexors & 0.95 & $0.71-0.99$ & $-25.8-22.3$ & 0.94 & $0.69-0.99$ & $-24.3-24.5$ & 0.95 & $0.71-0.99$ & $-24.6-23.7$ \\
\hline Knee extensors & 0.85 & $0.17-0.97$ & $-39.3-27.5$ & 0.92 & $0.55-0.98$ & $-27.6-24.6$ & 0.91 & $0.51-0.98$ & $-26.1-29.6$ \\
\hline
\end{tabular}

Note: $\mathrm{Cl}=$ Confidence interval. 
Table 5 - Intra-Class Correlation Coefficient (ICC) values for the inter-examiner reliability test using the AST to evaluate the strength of the hip abductor muscles; flexor and extensor muscles of the hip and knee, considering the repetitions in the two distinct sessions, including data from examiner 1 and 2

\begin{tabular}{|c|c|c|c|c|c|c|c|c|c|}
\hline \multirow[t]{2}{*}{$\begin{array}{l}\text { Muscular } \\
\text { Group }\end{array}$} & \multicolumn{3}{|c|}{ First Repetition } & \multicolumn{3}{|c|}{$\begin{array}{l}\text { Mean of the } 1^{\text {st }} \text { and } 2^{\text {nd }} \\
\text { Repetition }\end{array}$} & \multicolumn{3}{|c|}{$\begin{array}{c}\text { Mean of the } 1^{\text {st }}, 2^{\text {nd }} \text { and } 3^{\text {rd }} \\
\text { Repetition }\end{array}$} \\
\hline & ICC & $\begin{array}{l}95 \% \mathrm{Cl} \text { of } \\
\text { the ICC }\end{array}$ & $\begin{array}{c}95 \% \mathrm{Cl} \\
\text { of the } \\
\text { difference of } \\
\text { the means }\end{array}$ & ICC & $\begin{array}{l}95 \% \mathrm{Cl} \text { of } \\
\text { the ICC }\end{array}$ & $\begin{array}{c}95 \% \mathrm{Cl} \\
\text { of the } \\
\text { difference of } \\
\text { the means }\end{array}$ & ICC & $\begin{array}{l}95 \% \mathrm{Cl} \text { of } \\
\text { the ICC }\end{array}$ & $\begin{array}{c}95 \% \mathrm{Cl} \\
\text { of the } \\
\text { difference of } \\
\text { the means }\end{array}$ \\
\hline \multicolumn{10}{|c|}{ Examiner 1x2 Day 1} \\
\hline Hip abductors & 0.84 & $0.42-0.95$ & $-26.7-27.8$ & 0.88 & $0.58-0.97$ & $-22.46-25.83$ & 0.90 & $0.63-0.97$ & 20.71-25.32 \\
\hline Hip flexors & 0.90 & $0.63-0.97$ & $-26.6-5.1$ & 0.95 & $0.81-0.98$ & $-21.47-2.02$ & 0.97 & $0.89-0.99$ & $-18.8-0.2$ \\
\hline Hip extensors & 0.92 & $0.71-0.98$ & $-27.2-4.97$ & 0.96 & $0.85-0.98$ & $-22.3-1.16$ & 0.97 & $0.90-0.99$ & $-18.7-1.1$ \\
\hline Knee flexors & 0.93 & $0.62-0.98$ & $-16.4-47.8$ & 0.92 & $0.54-0.98$ & $-17-54.6$ & 0.90 & $0.45-0.98$ & $-23.9-55.6$ \\
\hline Knee extensors & 0.88 & $0.34-0.98$ & $-29.5-49.6$ & 0.90 & $0.43-0.98$ & $-28.6-42.7$ & 0.90 & $0.46-0.98$ & $-30.5-39.9$ \\
\hline \multicolumn{10}{|c|}{ Examiner $1 \times 2$ Day 2} \\
\hline Hip abductors & 0.78 & $0.20-0.94$ & $-10.6-49.2$ & 0.80 & $0.27-0.94$ & $-7.73-49.1$ & 0.84 & $0.41-0.95$ & $-9.2-41.8$ \\
\hline Hip flexors & 0.91 & $0.69-0.97$ & $14.78-44.7$ & 0.86 & $0.49-0.96$ & $3.6-42$ & 0.89 & $0.59-0.97$ & $1.61-37.5$ \\
\hline Hip extensors & 0.92 & $0.70-0.97$ & $-11.1-22$ & 0.94 & $0.79-0.98$ & $-6.4-20$ & 0.95 & $0.82-0.98$ & $-2.23-21.75$ \\
\hline Knee flexors & 0.95 & $0.73-0.99$ & $0.63-51.65$ & 0.96 & $0.80-0.99$ & $7.29-49.6$ & 0.95 & $0.72-0.99$ & $3.09-53.8$ \\
\hline Knee extensors & 0.94 & $0.70-0.99$ & $-14.53-32.8$ & 0.96 & $0.77-0.99$ & $-6.2-38.6$ & 0.93 & $0.60-0.98$ & $-5.1-56.14$ \\
\hline
\end{tabular}

Note: $\mathrm{Cl}=$ Confidence interval.

\section{Discussion}

Validity

In the present study, the regression analyzes were able to explain how the association between HHD and AST measurements occurred and could infer judicious data regarding the variations of HHD values obtained by AST. The coefficient of determination $\left(r^{2}\right)$ of the various muscle groups was categorical, varying from 0.58 to 0.85 , which means that at least $58 \%$ of the changes in the DPM measurements can be explained by the variations in the AST measurements, indicating that the data obtained through the AST are good predictors of those obtained by the HHD. In the study by Aguiar et al. (9), $r^{2}$ ranged from 0.54 to 0.77 for the hip and knee musculature. In the study by Souza et al. (10), $r^{2}$ ranged from 0.57 to 0.79 .

The equations presented in this study may help professionals to convert force measurement data, or that of other strength measurements, from $\mathrm{mmHg}$ to $\mathrm{N}$, which facilitates the comparison of data from the literature, following the clinical evolution of individuals based on scientific evidence.
In the present study, the three repetitions were considered for analysis $(11,20)$, with no differences being observed between them $(\mathrm{p} \geq 0.90)$. Other studies also did not identify differences $(9,10)$. In the study by Agnew (20), there were significant variations between the measurements, however, the researchers used the AST to evaluate manual grip strength $(\mathrm{p}<0.01)$.

\section{Test-Retest Reliability}

The test-retest reliability of the AST, considering the three repetitions and the two examiners, revealed ICC $\geq 0.81$ for the knee and hip flexor and extensor musculature and ICC $\geq 0.67$ for the hip abductors. In the study by Aguiar et al. (9), the test-retest reliability in subjects with hemiparesis ranged from 0.75-0.97 (ICC) for hip flexors and extensors; 0.86-0.97 (ICC) for abductors; $0.65-0.87$ and $0.76-0.91$ (ICC) for knee flexors and extensors. Moderate to very high correlations for hip flexors (ICC 0.66-0.93) and abductors (ICC $0.75-0.93$ ) were also observed in other studies $(23,35)$. A very high correlation was also observed for the hip extensors (ICC 0.90-0.91) 
(35). This indicates concordance between the present study and the aforementioned studies. Even with levers of different lengths the results of the ICC were similar.

Observing the ICC values in the test-retest evaluations for the hip abductors, moderate results were identified regarding the second evaluator ( 0.67 - 0.69), with a wide $95 \% \mathrm{CI}$, containing zero. The variability can be explained by the force generation being dependent on the length of the lever arm (12). Sherrington et al. (23) also observed a 12\% lower difference in the ICC in the abduction movement using the sphygmomanometer without modification, when compared to the HHD.

\section{Inter-examiner Reliability}

In this study, the inter-rater reliability of the AST generated results considered high or very high. For knee extensors and flexors, the ICC scores ranged from $0.88-0.96$. For the hip abductors the ICC was $\geq 0.78$. For the hip flexors and extensors the interrater ICC was $\geq 0.86$. No differences between the evaluators and the two days of evaluation were observed.

According to previous studies $(9,10,36)$, inter-rater reliability values have been found to present variability according to the sample investigated. While the ICC values observed for the hip extensors in the present study were very high, moderate inter-rater correlations (ICC $=0.67$ ) were found in a cohort of older adults (36). In individuals with subacute (9), and chronic (10) hemiparesis, the ICC were moderate, high and very high, (0.62 - 0.94 and 0.57-0.97) respectively, for the muscle groups evaluated in this study. Bohannon et al. (25) observed moderate to low values for inter-rater reliability in the hip abduction and ankle dorsiflexion movements, however, using the HHD.

\section{Clinical Considerations}

Studies that evaluate reproducibility (reliability and concordance) aim to evaluate the variability of a method or an instrument, to attenuate poor interpretations of data before and after interventions or observations $(9-11,36)$. With muscle groups of considerable functional magnitude, such as those evaluated in the present study, the importance of evaluating hip abductors and extensors and knee extensors in individuals with lower limb amputation, is emphasized. Individuals who have a short residual limb $(<15.1 \mathrm{~cm})$ deserve special attention because, when weak, these muscles alter the socket system, limiting acuity in basic tasks such as walking and standing up $(7,29)$. In the present study, since the level of amputation was different, presenting residual limbs of different sizes (mean $30.4 \mathrm{~cm}$ [10.4 SD]), the positioning of the equipment presented variability, however, always considering $5 \mathrm{~cm}$ to the distal end of the stump. According to biomechanics, the production of force is dependent on the size of the lever arm and the position of the joint $(7,29)$. This could present differences when comparing studies on the reliability of the AST. As no studies with amputees were found in the literature review, the comparison with the present results was performed with studies presenting different samples $(9-12,23,35,36)$. According to Pedrinelli et al. (7), the residual limb length does not cause interference when evaluations are performed with the use of prostheses. However, as the evaluations were performed without the use of prostheses in the present study, the force length ratio was preponderant.

In this study, the non-amputated side was not evaluated, since it is already evident that the variability of strength measurements is lower in the non-amputated limb, in which the strength and power are greater (7).

The researchers performed the test-retest with two examiners, reinforcing the methodological criteria. The majority of the studies investigated $(9-11)$ evaluated the reproducibility, intra-examiner reliability, with only one examiner. In addition to reliability, validity was also a subject of the study.

\section{Limitations}

Although valid and reliable, the AST can be limited when the individual has a force that exceeds $300 \mathrm{mmHg}$, the maximum limit of measurement of the equipment. In the present study, the participants presented different levels of lower limb amputation, with levers of varying lengths. Unfortunately, this is a process inherent and particular to the studies with amputations of corporeal segments $(3,7,15,29)$. Regarding the number of individuals evaluated, the ideal would be 11 individuals for each age group (10). However, as in the majority of 
the studies with similar samples $(2,7,14,15,29)$, the number of individuals evaluated was restricted. This is a common situation when using a sample of amputees, as well as in other health conditions that present different situations $(10,11)$.

\section{Conclusion}

The AST is a simple measurement method, with valid and reliable measurement capacity. In individuals with lower limb amputations evaluated by two independent examiners, the AST presented adequate concurrent criterion validity, testretest reliability and inter-rater reliability. After familiarization training, only one repetition was sufficient to reproduce valid and reliable results.

\section{References}

1. Reis G, Casa Jr AJ, Campos RS. Perfil epidemiológico de amputados de membros superiores e inferiores atendidos em um centro de referência. RESC. 2012;2(2):52-62.

2. Highsmith MJ, Kahle JT, Miro RM, Orendurff MS, Lewandowski AL, Orriola JJ, et al. Prosthetic interventions for people with transtibial amputation: Systematic review and meta-analysis of highquality prospective literature and systematic reviews. J Rehabil Res Dev. 2016;53(2):157-84.

3. Pauley T, Devlin M, Madan-Sharma P. A single-blind, cross-over trial of hip abductor strength training to improve Timed Up \& Go performance in patients with unilateral, transfemoral amputation. J Rehabil Med. 2014;46(3):264-70.

4. Raya MA, Gailey RS, Fiebert IM, Roach KE. Impairment variables predicting activity limitation in individuals with lower limb amputation. Prosthet Orthot Int. 2010;34(1):73-84.

5. Aytar A, Pekyavas NO, Ergun N, Karatas M. Is there a relationship between core stability, balance and strength in amputee soccer players? A pilot study. Prosthet Orthot Int. 2012;36(3):332-8.

6. van Velzen JM, van Bennekom CA, Polomski W, Slootman JR, van der Woude LH, Houdijk H. Physical capacity and walking ability after lower limb amputation: a systematic review. Clin Rehabil. 2006;20(11):999-1016.
7. Pedrinelli A, Saito M, Coelho RF, Fontes RB, Guarniero R. Comparative study of the strength of the flexor and extensor muscles of the knee through isokinetic evaluation in normal subjects and patients subjected to trans-tibial amputation. Prosthet Orthot Int. 2002;26(3):195-205.

8. Nolan L. Lower limb strength in sports-active transtibial amputees. Prosthet Orthot Int. 2009;33(3):230-41.

9. Aguiar LT, Lara EM, Martins JC, Teixeira-Salmela LF, Quintino LF, Christo PP, et al. Modified sphygmomanometer test for the assessment of strength of the trunk, upper and lower limbs muscles in subjects with subacute stroke: reliability and validity. Eur J Phys Rehabil Med. 2016 0ct;52(5):637-.

10. Souza LA, Martins JC, Teixeira-Salmela LF, Lara EM, Moura JB, Aguiar LT, et al. Validity and reliability of the modified sphygmomanometer test to assess strength of the lower limbs and trunk muscles after stroke. J Rehabil Med. 2014;46(7):620-8.

11. Silva SM, Correa FI, Silva PF, Silva DF, Lucareli PR, Correa JC. Validation and reliability of a modified sphygmomanometer for the assessment of handgrip strength in Parkinson's disease. Braz J Phys Ther. 2015;19(2):137-45.

12. Toohey LA, Noronha M, Taylor C, Thomas J. Is a sphygmomanometer a valid and reliable tool to measure the isometric strength of hip muscles? A systematic review. Physiother Theory Pract. 2015;31(2):114-9.

13. Kegel B, Burgess EM, Starr TW, Daly WK. Effects of isometric muscle training on residual limb volume, strength, and gait of below-knee amputees. Phys Ther. 1981;61(10):1419-26.

14. Boutwell E, Stine R, Gard S. Shock absorption during transtibial amputee gait: Does longitudinal prosthetic stiffness play a role? Prosthet Orthot Int. 2017;41(2):178-85.

15. Demirbuken I, Ozyurek S, Angin S. Altered movement strategies in sit-to-stand task in persons with transtibial amputation. Prosthet Orthot Int. 2014;38(4):303-9.

16. Moirenfeld I, Ayalon M, Bem-Sira D, Isakov E. Isokinetic strength and endurance of the knee extensors and flexors in trans-tibial amputees. Prosthet Orthot Int. 2000;24(3):221-5. 
17. Bohannon RW. Manual muscle testing: does it meet the standards of an adequate screening test? Clin Rehabil. 2005;19(6):662-7.

18. Dvir Z. Differentiation of submaximal from maximal trunk extension effort: an isokinetic study using a new testing protocol. Spine (Phila Pa 1976). 1997;22(22):2672-6.

19. Shahbabu B, Dasgupta A, Sarkar K, Sahoo SK. Which is MoreAccuratein MeasuringtheBloodPressure?ADigital or an Aneroid Sphygmomanometer. J Clin Diagn Res. 2016;10(3):LC11-4.

20. Agnew PJ, Maas F. Jamar Dynamometer and Adapted Sphygmomanometer for Measuring Grip Strength in Patients with Rheumatoid Arthritis. OTJR (Thorofare N J). 1991;11(5):259-70.

21. Chiu TT, Sing KL. Evaluation of cervical range of motion and isometric neck muscle strength: reliability and validity. Clin Rehabil. 2002;16(8):851-8.

22. Mahashabde R, Fernandez R, Sabnis S. Validity and reliability of the aneroid sphygmomanometer using a paediatric size cuff for craniocervical flexion test. Int J Evid Based Healthc. 2013;11(4):285-90.

23. Sherrington C, Lord SR. Reliability of simple portable tests of physical performance in older people after hip fracture. Clin Rehabil. 2005;19(5):496-504.

24. Bohannon RW. Reference values for extremity muscle strength obtained by hand-held dynamometry from adults aged 20 to 79 years. Arch Phys Med Rehabil. 1997;78(1):26-32.

25. Bohannon RW, Andrews AW, Thomas MW. Normative values for isometric muscle force measurements obtained with hand-held dynamometers. Phys Ther. 1996;76(3):248-59.

26. Souza LAC, Martins JC, Moura JB, Teixeira-Salmela LF, Paula FVR, Faria CDCM. Avaliação da força muscular com o teste do esfigmomanômetro modificado: qual o melhor método e forma de operacionalização? Braz J Phys Ther. 2014;18(2):191-200.

27. Nikolasjsen L, Jensen TS. Phantom limb pain. Br J Anaesth. 2001;87:107-16.
28. Alves AMB, Natour J, Assis MR, Feldman D. Avaliação de instrumentos de medida usados em pacientes com fibromialgia. Rev Bras Reumatol. 2012;52(4):496-506.

29. Isakov E, Burger H, Gregoric M, Marincek C. Stump length as related to atrophy and strength of the thigh muscles in trans-tibial amputees. Prosthet Orthot Int. 1996;20(2):96-100.

30. Portney LG, Watkins MP. Foundations of Clinical Research: Applications to Practice. 3rd ed. New Jersey: Prentice-Hall Health; 2009.

31. Thorborg K, Petersen J, Magnusson SP, Holmich P. Clinical assessment of hip strength using a handheld dynamometer is reliable. Scand J Med Sci Sports. 2010;20(3):493-501.

32. Kolk S, Fluit R, Luijten J, Heesterbeek PJ, Geurts AC, Verdonschot N, et al. Gait and lower limb muscle strength in women after triple innominate osteotomy. BMC Musculoskelet Disord. 2015;16:68.

33. Oliveira LC, Saad MC, Felício LR, Grossi DB. Muscle strength analysis of hip and knee stabilizers in individuals with Patellofemoral Pain Syndrome. Fisioter Pesqui. 2014;21(4):327-32.

34. Souza LAC, Martins JC, Teixeira-Salmela LF, Godoy MR, Aguiar LT, Faria CDCM. Avaliação da força muscular pelo teste do esfigmomanômetro modificado: uma revisão da literatura. Fisioter Mov. 2013;26(2):437-52.

35. Perossa DR, Dziak M, Vernon HT, Hayashita K. The intra-examiner reliability of manual muscle testing of the hip and shoulder with a modified sphygmomanometer: A preliminary study of normal subjects. J Can Chiropr Assoc. 1998;42(2):73-82.

36. Kaegi C, Thibault MC, Giroux F, Bourbonnais D. The interrater reliability of force measurements using a modified sphygmomanometer in elderly subjects. Phys Ther. 1998;78(10):1095-103.

Received in $06 / 27 / 2016$ Recebido em 27/06/2016

Approved in 05/12/2017 Aprovado em 12/05/2017 